\title{
A Spatial Representation of Delaware-Washington Interaction in Corporate Lawmaking
}

\section{Citation}

Mark J. Roe, A Spatial Representation of Delaware-Washington Interaction in Corporate Lawmaking, 2012 Colum. Bus. L. Rev. 553 (2012). Reprinted with the permission of the CBLR

\section{Permanent link}

http://nrs.harvard.edu/urn-3:HUL.InstRepos:32657892

\section{Terms of Use}

This article was downloaded from Harvard University's DASH repository, and is made available under the terms and conditions applicable to Other Posted Material, as set forth at http:// nrs.harvard.edu/urn-3:HUL.InstRepos:dash.current.terms-of-use\#LAA

\section{Share Your Story}

The Harvard community has made this article openly available.

Please share how this access benefits you. Submit a story. 
ISSN 1936-5349 (print)

ISSN 1936-5357 (online)

\title{
HARVARD
}

JOHN M. OLIN CENTER FOR LAW, ECONOMICS, AND BUSINESS

\author{
A SPATIAL REPRESENTATION OF \\ DELAWARE-WASHINGTON INTERACTION \\ IN CORPORATE LAWMAKING
}

Mark J. Roe

Discussion Paper No. 737

$10 / 2012$

Harvard Law School

Cambridge, MA 02138

This paper can be downloaded without charge from:

The Harvard John M. Olin Discussion Paper Series:

http://www.law.harvard.edu/programs/olin_center/

This paper is also a discussion paper of the

John M. Olin Center’s Program on Corporate Governance. 


\title{
A SPATIAL REPRESENTATION OF DELAWARE-WASHINGTON INTERACTION IN CORPORATE LAWMAKING
}

\begin{abstract}
Mark J. Roe*
Delaware and Washington interact in making corporate law. In prior work I showed how Delaware corporate law can be, and often is, confined by federal action. Sometimes Washington acts and preempts the field, constitutionally or functionally. Sometimes Delaware tilts toward or follows Washington opinion, even if that opinion does not square perfectly with its own consensus view of the best way to proceed. And sometimes Delaware affects Washington activity, effectively coopting a busy Washington from acting in ways that do not accord with Delaware's major constituents' view of best practice. Delaware influences Washington decision-making when Delaware is positioned between its own ultimate preferences (determined in part by its primary constituencies' consensus position) and Washington's prevailing preferences. Since Congress has a long and complex agenda, if key players in Washington become satisfied that the Delaware legal outputs are close enough to their own preferences, Delaware can induce Washington to desist from going further.

At the Columbia Symposium on Delaware corporate lawmaking, I presented a straight-forward spatial model paralleling spatial models that political scientists have used to illustrate other contexts of government jurisdictional interaction. In this article, I describe and set forth that model to illustrate Delaware-Washington interaction in the last decade's making of proxy access rules.
\end{abstract}

* David Berg Professor of Law, Harvard Law School. The substance of this paper was presented at the Columbia University School of Law Symposium: The Delaware Court of Chancery: Change and Continuity (Nov. 11, 2011). 
I. Introduction ......................................................... 554

II. Shareholder Voting Basics..................................... 556

III. Shareholder Access: Controversy and Action .......... 557

A. The SEC Considers Reconfiguring the Corporate Structure 557

B. Dodd-Frank Authorization and the SEC's Access Rule. 558

IV. Delaware's 2009 Shareholder Access Law and the

D.C. Circuit's Ruling

A. Delaware Legislates on Access in 2009: The New Section 112 559

B. The D.C. Circuit Court of Appeals Strikes Down SEC Rule 14a-11

V. A Simple Political Economy Model of Delaware Influence on Washington 561

A. The Immediately Relevant Political Economy Literature 564

B. As Applied to Delaware-Washington Interaction

VI. Conclusion 568

\section{INTRODUCTION}

We have now come to understand in academic corporate law analysis that Delaware and Washington D.C. are the principal jurisdictions making corporate law in the United States. Each makes major rules governing the interaction of boards of directors, shareholders, and senior managers in the large American public corporation. Often their lawmaking operates in parallel, with one jurisdiction affecting one dimension of corporate governance while the other jurisdiction affects a different dimension. Often their lawmaking is complementary, with both operating in the same dimension but in different ways. 1 Sometimes they act inconsistently, in tension.

1 See Mark J. Roe, Delaware's Competition, 117 HARV. L. REV. 588 (2003); see also William W. Bratton, Corporate Law's Race to Nowhere in Particular, 44 U. Toronto L.J. 401, 419 (1994); John C. Coffee, Jr., The 
And sometimes their lawmaking efforts do not move on parallel tracks but interact. Delaware, for example, sometimes makes its corporate law with a wary eye on Washington. At other times, the interactive positioning is more complex: when both jurisdictions are active, Delaware's positioning can affect Washington, whether or not Delaware intends to affect it. Elsewhere, I have argued that these twoway influences were in play in the last decade's intense corporate governance activity on shareholder access rules. 2 Here I sketch out how we can use a spatial model, of the type political scientists have built for different jurisdictional interactions, to illustrate this dimension of DelawareWashington interaction.

The application in political science focuses on how the Supreme Court and Congress have interacted in labor law decisionmaking. The central idea is that the Supreme Court positions itself somewhat away from its own ideal preferences, so as to minimize the chance that Congress acts to overturn Supreme Court decisions in this area. Action is costly for Congress and, as long as the Supreme Court's decisions are not too far from the preferences of the relevant congressional committee, a busy, difficult-to-organize Congress will do nothing. Aware of this likelihood, political scientists detect Supreme Court positioning that is consistent with it seeking to minimize the chance of Congress reversing it.

In this article, we see how this kind of political economy thinking can illustrate one dimension of DelawareWashington interaction in corporate lawmaking, using shareholder access as the template for analysis. Delaware's and Washington's main constituents have had differing views on the appropriate rules for shareholder access, with Delaware at first hostile to access and Washington

Future of Corporate Federalism: State Competition and the New Trend Toward De Facto Federal Minimum Standards, 8 CARDozo L. REV. 759, 768 (1987); Marcel Kahan \& Edward B. Rock, Symbiotic Federalism and the Structure of Corporate Law, 58 VAND. L. REV. 1573 (2005).

2 See Mark J. Roe, The Shareholder Vote and Its Political Economy, in Delaware and in Washington, 2 HARV. BUS. L. REV. (forthcoming 2012). 
sympathetic. When, after the 2008 election, Washington was likely to produce a strong shareholder access statute, Delaware in 2009 produced a moderate one. The moderate statute could have had an impact on Washington, and seemed to have been intended by influential players to affect Washington's decisionmaking. It could have dissuaded some busy players in Congress from acting on the issue, induced the Securities and Exchange Commission ("SEC") to backtrack, and conditioned the litigation environment to increase the chance that the courts would strike down aggressive SEC action. Some of these results did not come to pass, some did, and we can speculate as to whether there is a causal connection and whether there was serious intentionality in play.

A roadmap: In Part I, I briefly outline the corporate substance of the shareholder access controversy. In Part II, we see an overview of the SEC's access actions throughout the past decade. In Part III, we examine the end-of-thedecade, 2009, Delaware access statute and how its scope is narrower than what the SEC was proposing at the time. In Part IV, I use the spatial modeling from analogous political science visual representations of jurisdictional interaction to illustrate how Delaware's positioning could affect, could have been intended to affect, and may have actually affected, Washington decisionmaking and outputs on corporate shareholder power and access to the company's voting solicitation.

\section{SHAREHOLDER VOTING BASICS}

The voting structure for the large American public firm has long favored the authority of incumbent boards. Shareholders typically elect the board of directors annually, with few shareholders actually physically present at the annual meeting, but instead giving instructions for how to vote - a proxy - to someone else who will attend the meeting. Typically the company itself solicits proxy cards to allow incumbent management to cast shareholders' votes at the annual meeting. The company pays for this basic effort to 
solicit the votes of the firm's shareholders, with the board directing the company to solicit votes to elect the incumbent board or its chosen successors.

Insurgents are free to run against the incumbent directors, but they must pay for their own solicitation of votes from shareholders, pay for their own legal counsel (as proxy solicitations for shareholders' votes are highly regulated), and typically will not see their expenses reimbursed by the company. Corporate reformers have long sought to make insurgents' election easier, and shareholder access to the company's proxy solicitation was one of the reformers' central efforts in the post-2000 decade. Via proxy access, insurgents would be empowered to nominate a few directors and place those nominations in the company-paid proxy solicitation. If able to piggy-back on the company's election machinery, they could more readily challenge a corporate citadel of director authority.

\section{SHAREHOLDER ACCESS: CONTROVERSY AND ACTION}

While corporate reformers have long sought shareholder access to the company-paid proxy statement and the SEC has intermittently considered an access rule, it burst onto the scene as a central reform-in-the-making after the Enron scandal in 2002.

\section{A. The SEC Considers Reconfiguring the Corporate Structure}

In 2003, the SEC proposed that qualified shareholders have direct access to the company-paid proxy solicitation, to elect a minority slate of directors. While at first this was seen to be an inevitable reform, 3 persistent criticism from managers and their law firms induced the SEC to pull back. Criticism was directed both at the cumbersome mechanics of the proposal as made and at the theory overall-managerial

3 See Stephen Labaton, S.E.C. to Revise Election Rules for Directors, N.Y. Times, Oct. 1, 2003, at C1. 
interests argued that divided boards would be a cure worse than the disease. 4 Board proponents saw a partial capacity of dissident shareholders to elect directors as a pernicious shift of power in the boardroom. Independent directors might feel a gravitational pull to the shareholder-elected directors' program, away from that of the managers and other incumbents. We could array these preferences for and against shareholder access along a spectrum, as in Figure 1.

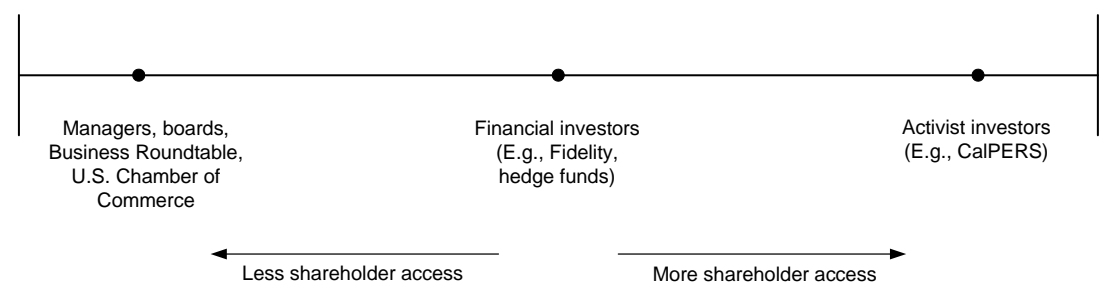

FIGURE 1. THE ARRAY OF INTERESTS.

Criticism-and perhaps raw lobbying power-eventually led the SEC to reconsider and ultimately abandon its 2003 proxy access proposal. Later, in 2007, it brought forward a modified proposal, but it too did not go final. It took the financial breakdown of 2008 to facilitate shareholder access breaking through into final SEC rules.

\section{B. Dodd-Frank Authorization and the SEC's Access Rule}

During the financial crisis of 2008 and 2009, sympathy rose again for corporate and finance reform proposals of all sorts and proxy access came back as a live reform issue, despite its limited connection with the crisis. Doubts were expressed as to whether the SEC had authority to promulgate proxy access, because proxy voting had both

4 See, e.g., Letter from Seven Law Firms to Elizabeth Murphy, Sec'y, U.S. Sec. \& Exch. Comm'n (Jan. 19, 2010) (regarding facilitating shareholder director nominations); Martin Lipton \& Steven A. Rosenblum, Election Contests in the Company's Proxy: An Idea Whose Time Has Not Come, 59 Bus. LAw. 67 (2003); Stephen Labaton, S.E.C. Member Says Agency Has Bowed to Executives, N.Y. Times, Oct. 9, 2004, at B1. 
elements of securities regulation, which were appropriate regulatory matters under the securities laws, and had aspects of basic corporate voting, which were ordinarily matters addressed by state corporate law-typically that of Delaware.5 In the reform atmosphere of that moment, Senator Charles Schumer proposed to explicitly authorize SEC rulemaking on proxy access and such a provision made its way into the final reform legislation, the Dodd-Frank Act, 6 which the SEC acted upon in 2010.7

\section{DELAWARE'S 2009 SHAREHOLDER ACCESS LAW AND THE D.C. CIRCUIT'S RULING}

\section{A. Delaware Legislates on Access in 2009: The New Section 112}

For much of the decade, Delaware had been quiet as to shareholder access, and at times hostile to it. When shareholder insurgents sought by-laws that would permit shareholder access, Delaware lawyers opined that Delaware law barred access, and reserved such election decisions to the company's board of directors, not its shareholders. A Delaware Supreme Court decision in the area indicated that the by-laws needed to keep discretion with directors to avoid such types of by-laws if the board thought the election by-law was not in the interests of shareholders. The corporation, its shareholders, and the board could not bind themselves in advance to specific election rules here. 8

However, in March 2009, as the SEC renewed its interest in access, Delaware amended its corporate law with its new Section 112, which permitted shareholders inexpensive

5 See Bus. Roundtable v. SEC, 647 F.3d 1144 (D.C. Cir. 2011).

6 See Dodd-Frank Wall Street Reform and Consumer Protection Act, Pub. L. No. 111-203, § 971, 124 Stat. 1376, 1915 (2010) (to be codified at 15 U.S.C. $\S 78 n)$.

7 Facilitating Shareholder Director Nominations Final Rule, 75 Fed. Reg. 56,668 (Sept. 16, 2010).

8 See CA, Inc. v. AFSCME Employees Pension Plan (Computer Associates), 953 A.2d 227 (Del. 2008). 
access to the company paid-for proxy solicitation, if the corporate by-laws so provided:

The bylaws ... may provide that if the corporation solicits proxies with respect to an election of directors, it may be required ... to include in its proxy solicitation materials ... in addition to individuals nominated by the board of directors, 1 or more individuals nominated by a stockholder.9

Delaware's access statute was moderate, compared to what the two access rules that the SEC was considering. The strongest (and most controversial) would have mandated that public firms accord proxy access to shareholders with $3 \%$ or more of the total shareholder vote, if they had held their stock for several years. The second would have required that shareholders could make their own proxy rules and that the corporation would have to give access to the company-paid proxy statement for shareholder rulemaking proposals on such voting access rules.

The latter structure seems technical but sharply allocates power between insurgent shareholders and boards of directors, making shareholder access much easier in practice. In contrast, the Delaware access statute does not allow shareholders access to the company proxy solicitation so that they could have a cheap shareholder vote on access rules. Rather, the insurgents must convince the board to promulgate such a rule, or they must run an expensive proxy solicitation themselves. That is, to get access to avoid an expensive proxy fight, the insurgents would have to run an often-expensive proxy fight first. The second SEC rule would make that kind of circular effort - a preliminary proxy contest to get an inexpensive proxy contest - unnecessary.

\section{B. The D.C. Circuit Court of Appeals Strikes Down SEC Rule 14a-11}

As noted above, proxy access was controversial and fiercely opposed by most boards and their organizations.

9 Del. Code Ann. tit. 8, § 112 (2012). 
During the access reform decade, the powerful and influential Business Roundtable-managers' and directors' main lobbying organization-regularly indicated that it would challenge an SEC proxy access rule as beyond the SEC's authority. Senator Schumer's proposed congressional authorization of the SEC on access, which was folded into the Dodd-Frank financial reform legislation, reacted to these criticisms.

Even with the Dodd-Frank authorization in place, the Business Roundtable challenged the SEC's broadest rule and the D.C. Circuit Court struck the rule down.10

\section{A SIMPLE POLITICAL ECONOMY MODEL OF DELAWARE INFLUENCE ON WASHINGTON}

Parts II and III set forth the decade's main regulatory, legislative, and judicial action on proxy access. Here in this Part, I first outline the potential explanations for Delaware's moderate access statute and then show how extant political economy models can be used to illustrate two of the Delaware-Washington interactive possibilities.

Uncovering Delaware's motivations is not easy, because the legislative history of Section 112 has no formal record and because different players must have had differing and sometimes mixed motives. Even the basics of legislative history are unavailable: the Delaware Corporate Law Council, composed of leading members of the Delaware corporate bar, recommended the legislation and the Delaware legislature then enacted it. There is no further formal legislative history.

Potential intentions can be hypothesized by examining the explanations leaders in the corporate bar gave and by considering these explanations against the logic of the situation. The potential explanations start with the purely public-oriented with limited reference to Washington-some Delaware leaders had always favored some sort of access 11

10 See Bus. Roundtable, 905 F.2d 406.

11 See Leo E. Strine, Breaking the Corporate Governance Logjam in Washington: Some Constructive Thoughts on a Responsible Path Forward, 
and they could have seen the Washington agenda as providing their moment to get a moderate access statute enacted. The drafters may have wished to clarify Delaware's corporate law and reiterate Delaware's longstanding enabling approach with the initial decisionmaking authority lying with the board of directors, not the company's shareholders. 12

Explanations could also be public-oriented but positioned with Washington's likely promulgation following the 2008 election in mind. If access was inevitable, responsible Delaware leaders could well have thought they would manage access better than Washington. Or more broadly, but still with reference to Washington, Delaware's inside leaders may have thought that they needed to assert a Delaware corporate reform presence in light of the financial crisis and the 2008 election.

And the potential explanations include a nearly Machiavellian hypothesis that a few Delaware players, or corporate players with influence in Delaware, could have thought they might slow Washington down by enacting a moderate form of access. Washington might think twice, or act less boldly, due to Delaware law's potential impact in three different arenas: Congress, the SEC, and the courts. Congress might have been satisfied with a Delaware statute and, as such, then ignored Schumer's proposal to explicitly authorize the SEC to promulgate access. The SEC might have let access slide off its crowded rule-making agenda once again if Delaware had a usable access rule in place. Courts might be more inclined to strike down an SEC rule on federalism grounds (especially before its authority was specifically expanded with the Schumer section in DoddFrank) if the rule explicitly conflicted with major state

63 Bus. LaW. 1079, 1081 (2008); Leo E. Strine, Remarks at the Roundtable Discussions Regarding the Federal Proxy Rules and State Corporation Law 34 (May 7, 2007), available at www.sec.gov/spotlight/proxyprocess/ proxy-transcript050707.pdf; see also William T. Allen, Jack B. Jacobs \& Leo E. Strine, Jr., The Great Takeover Debate: A Meditation on Bridging the Conceptual Divide, 69 U. CHI. L. REv. 1067, 1097 (2002).

12 Cf. Computer Associates, 953 A.2d at 232. 
legislation already on the books, as Delaware's Section 112, by March 2009, had become. More generally, Delaware media reported during the 2008 election that leading Delaware "lawyers are calling for Delaware to throw water on the fire [of federal corporate lawmaking activity] before the national election by tweaking the state's corporate law to address growing concerns among stockholders."13

Elsewhere I examine the available evidence in more detail,14 but here it is sufficient to report a few relevant items. First, the Delaware bar told the SEC not to move forward on access, because Delaware's lawmaking was more flexible than the SEC's and because an SEC rule would "undermine ... the state system of corporate governance." 15 This Delaware effort suggests that some players were aware that an explicit, new enactment of the substance of access via Section 112 could induce some Washington decisionmakers who were respectful of federalism and state lawmaking to pull back from access. A leader in the corporate bar offered a more direct and cogent explanation, saying that Delaware sought "to forestall these attempts [from the SEC and from Congress] to further federalize corporate law."16 Sophisticated Delaware players, such as the Vice Chancellor, advise the state's corporate constituents to use some form of Delaware's proxy access or face the

13 Maureen Milford, Delaware's corporate dominance threatenedFederal intervention could put at risk a third of state's budget, NEWs J., Mar. 2, 2008, at A1.

14 Roe, supra note 2. I put forward related, but more general political economy explanations for corporate outcomes in Mark J. Roe, STRONG Managers, Weak Owners: The Political Roots of American Corporate Finance (1994), and Mark J. Roe, A Political Theory of American Corporate Finance, 91 ColUM. L. REV. 10 (1991).

15 Letter from Del. State Bar Ass'n to Elizabeth M. Murphy, Sec'y, U.S. Sec. \& Exch. Comm'n (July 24, 2009) (regarding facilitating shareholder director nominations), available at http:/www.sec.gov/ comments/s7-10-09/s71009-65.pdf.

16 Theodore Mirvis, Strategies for the New Reality of Shareholder Proxy Access, HLS Forum (May 14, 2009), available at http://blogs.law. harvard.edu/corpgov/2009/05/14/strategies-for-the-new-reality-ofshareholder-proxy-access/. 
possibility that "you're going to get something more detailed [from the SEC than is Delaware Section 112 and] that won't have the same type of outcome" as Rule 14a-11, which was struck down by the D.C. Circuit Court of Appeals. ${ }^{17}$

\section{A. The Immediately Relevant Political Economy Literature}

Spatial models, which many political scientists favor, facilitate our understanding of the Delaware-Washington interaction.18 In examining Supreme Court labor law decisions, Professor Pablo Spiller has seen the court tilting away from its own bottom-line views to produce outputs closer to those of the relevant committees in Congress. If a Court decision is close enough to the committee's views, the committee may leave the Supreme Court decision in place, even if it was not identical to the committee's own preferences. But, if the Court moves on its own preferences with decisions that sharply conflict with congressional preferences, then the congressional committee might be induced to act, with the ultimate rule resting far from the Court's own preferences:

[The Supreme] Court is restricted . . . by the ability of Congress to overturn its decisions. The Court, then, cannot deviate too much from what Congress's independent legislative outcome would be without facing a reversal. So even though Congress may not

17 Yin Wilczek, Proxy Access: Del. Judge Urges Corps. To Use Private Ordering Access Regime, 27 BNA CCW 03 D21 (Jan. 18, 2012).

18 See, e.g., Mario Bergara, Barak Richman \& Pablo T. Spiller, Modeling Supreme Court Strategic Decision Making: The Congressional Constraint, 28 LEG. STUD. Q. 247, 248-49 (2003); Pablo T. Spiller \& Rafael Gely, Congressional Control or Judicial Independence: The Determinants of U.S. Supreme Court Labor-Relations Decisions, 1949-1988, 23 RAND J. ECON. 463, 465 (1992); see also William N. Eskridge, Overriding Supreme Court Statutory Interpretive Decisions, 101 YALE L.J. 331, 335 (1991); John Ferejohn \& Barry Weingast, A Positive Theory of Statutory Interpretation, 12 INT'L J.L. \& Econ. 263 (1992); Anna Harvey \& Barry Friedman, Ducking Trouble: Congressionally Induced Selection Bias in the Supreme Court's Agenda, 71 J. Politics 574, 574-76 (2009). 
be actively legislating, it does not follow that it has actually relinquished legislative responsibility to the Court, or that the Court is dictatorial.19

\section{B. As Applied to Delaware-Washington Interaction}

The interests and their preferences are shown in Figure 1 above: managers, activist investors, and financial investors. Managers prefer that no shareholder have access to the company's proxy statement, as access would intrude on managerial autonomy. Activist investors seek easy access, with minimal prerequisites to access. Financial shareholders do not seek broad access but do want to limit some types of managerial autonomy. Figure 1 illustrates the range of interests in their preference for more, or for less, shareholder access.

Next, we place the original positions of the main government bodies in this spectrum. We position the SEC, an agency that has investor protection as its raison d'être and in recent years has been influenced by public pension funds and activist investors, between the preferences of financial and activist investors. Delaware is initially positioned between managers' and investors' preferences. The SEC prefers access, but that preference was not strong at the beginning of the decade, before the Enron and WorldCom scandals and the passage of the Sarbanes-Oxley Act to reform corporate governance. It was not active in promoting access in the year 2000 .

Consider this as the play of interests and positions of government authorities, circa 2000. Figure 2 illustrates, with the gray circles indicating position but the gray shading reflecting inaction.

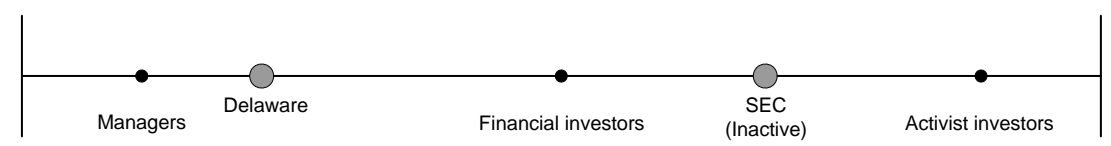

FIGURE 2. STATE-FEDERAL PREFERENCES, CIRCA 2000.

19 Spiller \& Gely, supra note 18, at 465. 
The first action to explain is why Delaware enacted a moderate shareholder access law in 2009, illustrated via the first arrow in Figure 3:

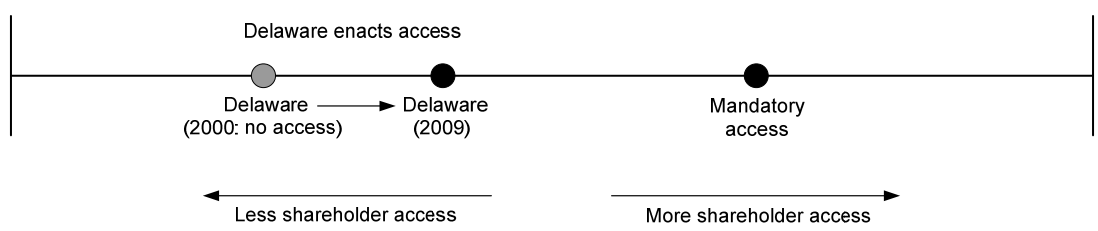

\section{Figure 3. DElaWARE MOVES From No ACCESS} TO MODERATE ACCESS.

One explanation (but not the only one20) for Delaware's movement is that it was pulled along in Washington's wake. After scandals such as Enron in 2001 and WorldCom in 2002, and again after the 2008 financial crisis, the SEC actively promoted shareholder access and Congress considered expanding SEC statutory authority to promulgate access rules. In normal times, access is neither on the congressional agenda nor high on the SEC's. Crisis and scandal motivate each toward action. Figure 4 illustrates, with the dark circles indicating position and activity.

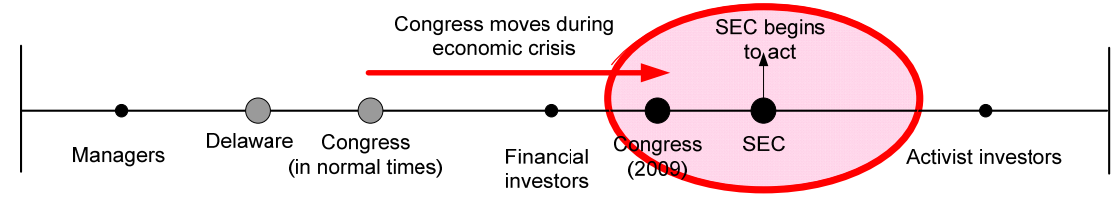

FIGURE 4. ACTION IN WASHINGTON.

According to this view, Washington activity pulled Delaware rightward in this array, away from opposing and then toward mildly favoring access, as shown in Figure 5. It might have moved rightward so as to not be too far from the corporate consensus, or it might have moved rightward because it too became convinced that some sort of access was justified and ought to benefit from Delaware corporate law's typical enabling approach. But it could also have moved 
rightward for more Machiavellian reasons. For the latter possibility, we would need to think of Delaware as being more nimble than the Washington players. It repositions itself quickly in light of Washington tendencies and, in 2008 and 2009, assessing both where Congress stood and the likelihood of SEC action, it moves quickly. It does so in order to stay relevant when Washington is in motion, to reduce the chance that either Congress or the SEC acts (because, although Delaware's new position is not at either Congress's or the SEC's ideal points, its new position might be good enough to induce one or the other in Washington to stop), and perhaps to set up political and judicial federalism challenges to SEC shareholder access action.21 Or its moves have those effects, as shown in Figure 5, which shows Delaware acting because Washington had put access onto the corporate reform agenda.

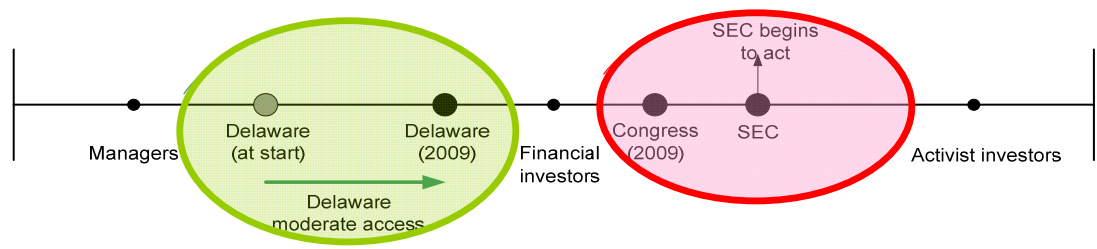

FIGURE 5. A WASHINGTON-CENTERED GRAVITATIONAL PULL ON DELAWARE CORPORATE LAWMAKING?

A more subtle effect of, and possibly an explanation for, the moderate Delaware statute is that it could have induced, and perhaps was intended by some to induce, one or another

21 One might ask why Delaware did not act similarly in 2003 and 2005. Perhaps the relevant players just did not think of the maneuver. Another possibility is that it took awhile, after a half-dozen years of federal percolation, for Delaware to interest itself in the issue. Another, less charitable, explanation is that those opposing access in 2003 thought the best strategy was to take it head-on at the federal level, by using political muscle and influence in Congress and on the White House to influence the SEC. A Delaware foray could have weakened the direct effort. After the 2008 elections, their muscle in Congress and the White House diminished, calling for different tactics. 
of the critical Washington players (the Congress, the SEC, the Circuit Court of Appeals) to back off on access. While interaction is in play even if Delaware never intended its statute to have that kind of effect-effects are not always intended-it is of course also possible that some in Delaware, infused with a little Machiavellian perspicacity, intended such an effect.

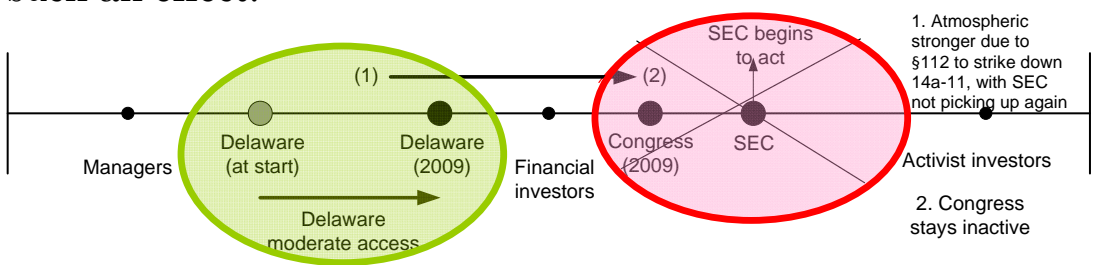

FIGURE 6. CAN DELAWARE ACTION MODERATE OR CO-OPT WASHINGTON?

This spatial, illustrative analysis for federal-state interaction gives us a conceptual array of the jurisdictional forces and pressures in making corporate law in America. It does not tell us whether lawmaking results are more efficient at one level or another. But with the spatial arrays in mind, we are better positioned than before to understand the corporate lawmaking pressures and process.

\section{CONCLUSION}

We have examined the federal-state jurisdictional interaction in making American corporate law. Shareholder access to the company paid-for proxy solicitation was central to the reform agenda in the decade following the 2001-03 Enron and WorldCom scandals. The SEC proposed and let die several proposals, eventually promulgating two rules at the end of the decade, the most expansive of which the D.C. Circuit struck down.

During the same period, Delaware moved from indifference or even hostility to access to enacting an accessenabling statute. Two of the possible analyses of the interaction are, first, that Delaware moved because it thought it could not stay too far behind the Washington action and, second, that its moderate action could have the 
effect of slowing down or even coopting federal action. The first view portrays the interaction as a one-way street, with Washington influencing Delaware. The second view sees jurisdictional interaction as a two-way street.

These potential jurisdictional interactions map nicely onto political scientists' spatial models of political positioning. The figures in the body of the article illustrate that federal-state interaction. 